\title{
PARTISIPASI MASYARAKAT DALAM PENGELOLAAN SUMBER DAYA ALAM (SDA) HUTAN DI SEKITAR GUNUNG LOLOMBULAN
}

\author{
Tommy M. Palapa \\ Prodi Pendidikan Biologi, Fakultas Matematika dan Ilmu Pengetahuan Alam, UNIMA \\ tommypalapa@yahoo.com
}

\begin{abstract}
Abstrak
Pelaksaaan kegiatan pengabdian masyarakat dilaksanakan dengan tujuan untuk meningkatkan pengetahuan dan pemahaman yang jelas dan benar tentang pengelolaan sumber daya alam (SDA) hutan yang ada di sekiatar gunung Lolombulan. Selain itu kegiatan ini dilaksanakan untuk meningkatkan sikap dan perilaku masyarakat tentang pengelolaan SDA hutan di sekitar gunung Lolombulan. Kegiatan ini dilaksanakan dalam 2 tahap yaitu pelatihan dan kegiatan penanaman pohon. Kegiatan pelatihan dilaksanakan pemahaman praktis tentang pentingnya menjaga hutan sebagai sumber daya alam serta teknis melaksanakan penanaman kembali hutan yang telah rusak, selanjutnya pelaksanaan kegiatan penanaman kembali hutan yang telah rusak. Kegiatan yang sifatnya penjelasan diikuti oleh tokoh-tokoh masyarakat, sedangkan penanaman diikuti oleh pemuda, pelajar, mahasiswa yang berasal dari desa Raanan Baru. Hasil yang diperoleh dalam kegiatan ini adalah meningkatnya pengetahuan masyarakat tentang pentingnya pelestarian hutan yang ada di sekitar gunung Lolombulan, serta berhasilnya menanam pohon sebagai upaya penghijauan kembali sebanya 400 pohon di sekitar sumber air yang ada di gunung Lolombulan. Kesimpulan yang diperoleh adalah terjadi peningkatan pengetahuan masyarakat tentang pentingnya pelestarian hutan yang ada di sekitar gunung Lolombulan. Terdapat peningkatan minat dan partisipasi masyarakat dalam melestarikan hutan di sekitar gunung Lolombulan.
\end{abstract}

Kata Kunci: Partisipasi masyarakat, pengelolaan SDA, dan Gunung Lolombulan..

\section{PENDAHULUAN}

\section{Analisis Situasi}

Hutan merupakan sumber daya alam (SDA) yang sangat strategis dalam menunjang kehidupan umat manusia. Fungsi strategis ini terkait dengan fungsi ekologis dan fungsi social hutan yang tidak terlepas dari kehidupan manusia. Hutan sebagai suatu ekosistim darat mempunyai fungsi sebagai pengatur keseimbangan iklim mikro yang akan berhubungan dengan kehidupan manusia seperti pengatur kestabilan suhu dan kebersihan udara yang ada di sekitar manusia. Hutan dengan segala keragaman vegetasi yang ada akan mampu memproduksi oksigen yang tidak terhingga sehingga mampu menjaga kestabilan suhu yang ada disekitarnya. Produktifitas oksigen yang terjadi di sekiatar hutan akan mempu mencukupi kebutuhan mahluk hidup yang ada disekitarnya termasuk manusia. Fungsi lain dari hutan adalah fungsi social ekonomis, dimana dengan adanya sumberdaya hutan aktifitas-aktifitas social kemanusiaan dapat berlangsung dengan baik.

Dewasa ini dengan makin besarnya upaya manusia mengekploitasi hutan, telah berdampak pada makin sempitnya lahan yang ditumbuhi hutan, sehingga makin sempit pula kesempatan manusia untuk menikmati fungsi hutan sebagai sarana hiburan. Karena itu di berbagai tempat telah diupayakan agar supaya hutan dapat dimanfaatkan sebagai sarana hibran/ rekreasi dan pengembangan ilmu 
pengetahuan. Selain itu pula hutan berfungsi ekonomis karena dari hutan dapat di ekploitasi hasil hutan berupa kayu, rotan dan produk-produk lain yang mempunyai nilai ekonomis tinggi.

\section{Beberapa fungsi hutan yang} diuraikan di atas telah mendorong manusia untuk mengeksploitasi hutan dengan membabi buta tanpa memepertimbangkan resiko dan akibat dari kegiatan tersebut. Akibat dari kegiatan penebangan yang tidak terkendali, dewasa ini diberbagai wilayah telah terjadi penggndulan htan yang berakibat pada menurunnya fungsi hutan, baik secara ekologis maupun secara social ekonomi.

Gunung Lolombulan adalan salah satu gunung yang ada di daerah Minahasa Selatan dengan fungsi utama adalah sumber utama air untuk air minum dan pertanian di sebagain besar wilayah Minahasa Selatan. Kondisi hutan yang ada di sekitar gunung Lolombulan mulai terindikasi mulai terancam karena berbagai kegiatan masyarakat yang mengganggu ekosistim hutan seperti penebangan, perkebunan, dan aktifitas lain yang sering dilakukan oleh orang-orang tidak bertanggung jawab.

Desa Raanan Baru adalah salah satu desa yang teletak di sisi Timur gunung Lolombulan dengan jarak sekitar $2 \mathrm{~km}$ dari kaki gunung. Karena letaknya yang dekat dengan gunung sehingga peran masyarakat sangat strategis untuk berpartisipasi dalam pengelolaan hutan, namun sampai saat ini partisipasi masyarakat baik secara langsung maupun tidak langsung belum maksimal. Karena itu melalui kegiatan pengabdian ini diupayakan bagaimana melibatkan masyarakat dalam upaya melestarikan hutan yang ada di sekitar gulung Lolombulan.

\section{Perumusan Masalah}

Berdasarkan pada beberapa uraian di atas, maka masalah yang ingin dipecahkan dalam kegiatan ini adalah:

1. Bagaimana pemahaman masyarakat tentang pengelolaan sumberdaya Hutan di sekiatar gunung Lolombulan?

2. Bagaimana partisipasi masyarakat dalam upaya mengelola sumberdaya alam Hutan sebagai sumber air utama.

\section{Tujuan dan Manfaat}

Berdasarkan uraian pemasalahan yang telah dikemukakan dalam pendahuluan di atas, maka tujuan kegiata pengabdian ini dapat dirumuskan sebagai berikut :

1. Untuk memberikan pemahaman yang jelas dan benar tentang pengelolaan sumberdaya alam hutan yang ada di sekitar gunng Lolombulan. Pemahaman ini dimaksud berkatan dengan bagaimana masyarakat memahami tentang pengetahuan dasar berkaitan dengan pengelolaan sumberdaya alam terutama hutan yang merupakan bagian dari kegiatan dan kebutuhan hidup sehari-hari. Pemahaman pengelolaan yang jelas akan sangat membantu 
realisasi program pelestarian sumber daya alam yang telah diprogramkan pemerintah; dan

2. Untuk meningkatkan minat dan partisipasi masyarat tentang pengelolaan sumber daya alam hutan di sekitar gunung Lolombulan. Minat masyarakat berkaitan erat dengan sikap terhadap sesuatu obyek. Jika sikap seseorang positif terhadap sesuatu obyek, maka secara otomatis akan membentuk sikap positif terhadap obyek tersebut. Demikian pula kaitan dengan upaya pelestarian sumber daya alam yang berkaitan dengan pelsterian hutan, jika minat masyarakat tinggi, akan mendorong partisipasi aktif dalam bentuk kegiatan nyata serta sehinga diharapkan pelestarian hutan akan berlangsung dengan baik sesuai dengan apa yang diharapkan para pengambil kebijakan.

Dari tujuan yang ditentukan, diharapkan manfaat yang diperoleh dari kegiatan pengabdian ini adalah sebagai berukut :

1. Masyarakat memperoleh pengetahuan baik secara teori maupun praktis tentang pengelolaan sumber daya alam ( hutan) yang merupakan sumber kehidupan masyarakat. Memperoleh pengetahuan yang cukup tentang pentingnya pelestarian hutan dianggap penting karena akan menjadi dasar dalam upaya mendorong partisipasi masyarakat yang hidup di sekitar wilayah hutan; dan

2. Masyarakat dapat secara sadar berpartisipasi secara langsung mengelola dan melestarikan hutan secara benar dan bertanggung jawab. Partisipasi masyarakat merupakan langkah strategis dalam upaya pelestarian hutan. Hal ini dimungkinkan karena jika dilihat dari kebutuhan, masyarakat sekitar daerah hutan sangat tergantung dari keberadaan hutan tersebut.

\section{Kerangka Pemecahan Masalah}

Pembangunan bidang kehutanan merupakan bagian integral dari pembangunan nasional sehingga menjadi jelas bahwa pembangunan bidang kehutanan merupakan tanggung jawab bersama, oleh karenanya harus dilaksanakan secara bertanggung jawab dan transparan untuk memberikan manfaat yang sebesar-besarnya bagi kemakmuran rakyat. Dalam praktek pengelolaan sumberdaya hutan harus tetap memperhatikan aspek ekologi, ekonomi dan aating budaya sehingga pemanfaatan sumberdaya hutan tidak hanya diarahkan untuk menghasilkan keuntungan ekonomi semata tetapi yang lebih penting adalah keberlanjutan fungsi sumberdaya hutan itu sendiri untuk menopang kehidupan manusia antar generasi.

Sebagaimana telah diketahui bersama bahwa dunia kehutanan pernah 
mengalami masa suram yakni pada saat sumberdaya hutan dikelola secara sentralistik dan hanya diperah untuk menghasilkan devisa dalam rangka perbaikan ekonomi. Keadaan ini terjadi pada awal kekuasaan orde baru, yang diawali dengan dikeluarakannya UU No. 5 Tahun 1967. Memang akibat kebijakan tersebut kehutanan mampu menduduki ranking kedua setelah migas sebagai penghasil devisa. Tetapi di balik semua itu telah terjadi degradasi dan kerusakan sumberdaya hutan secara besar-besaran, semakin tajamnya konflik antara pengelola (HPH) dengan masyarakat sekitar hutan juga terjadinya ketegangan antara pemerintah daerah dengan pemerintah pusat akibat sharing benefit yang tidak adil.

Seiring dengan semangat reformasi di segala bidang maka pada tahun 1999 pemerintah telah menerbitkan beberapa kebijakan yang diharapkan mampu untuk mengatasi permasalahan-permasalahan tersebut. Peraturan perundangan yang dimaksud antara lain UU No. 41 Tahun 1999 tentang Kehutanan, UU No. 22 Tahun 1999 tentang Pemerintahan Daerah, UU No. 25 Tahun 1999 Perimbangan Keuangan antara Pemerintah Pusat dan Pemerintah Daerah, serta Peraturan Pemerintah No. 25 tahun 2000 tentang Kewenangan Pemerintah Pusat dan Pemerintah Propinsi Sebagai Daerah Otonom. Yang perlu dicatat adalah bahwa keempat kebijakan tersebut dikeluarkan untuk merespon tuntutan reformasi sehingga di dalamnya dijiwai oleh semangat desentralisasi dan otonomi daerah yang sangat kuat. Hal ini dapat dipandang sebagai harapan baru bagi pengelolaan sumberdaya hutan di masa yang akan datang tetapi juga dipandang sebagai ancaman. Dipandang sebagai harapan karena dengan otonomi daerah diharapkan pengelolaan sumberdaya hutan akan lebih demokratis dan hasilnya langsung dapat dinikmati oleh daerah secara lebih merata.

Berdasarkan beberapa konsep dan teori dan permasalahan yang telah dikemukakan di atas, maka dibangun kerangka pemecahan permasalahan sebagai berikut :

1. Mengadakan pengujian sejauh mana pemahaman masyarakat tentang pentingnya pelestarian hutan sebagai bagian dari kelangsungan hidup baik sebagai bagian dari ekosistim maupun sebagai sumber ekonomi kerakyatan;

2. Mengadakan kegiatan pelatihan dengan materi ekosistim hutan dan peran masyarakat terhadap upaya pelestarian hutan lindung sebagai bagian dari ekosistim.

Sehubungan dengan strategi pelaksanaan tersebut di atas, maka tahapan-tahapan kegiatan yang dilaksanakan sebagai berikut :

1. Mengadakan uji awal pada peserta untuk mengetahui kemampuan awal peserta tentang pentingnya pelestarian hutan lindung sebagai bagian dari suatu ekosistim. 
2. Mengadakan pelatihan/ workhop bagi peserta tentang teknik penanaman pohon dalam upaya rehabilitasi hutan yang telah terjadi penebangan serta upaya untuk melibatkan seluruh komponen masyarakat dalam meningkatkan fungsi hutan.

\section{METODE PELAKSANAAN}

\section{Tempat Pelaksanaan}

Kegiatan ini dilaksanakan di Desa Raanan Baru Kecamatan Motoling Barat, Kabupaten Minahasa Selatan.

\section{Peserta dan Narasumber}

Peserta adalah seluruh Hukum Tua yang ada di Desa Raanan Baru Maesa (Raanan Baru, Raanan Baru I, dan Raanan Baru II), seluruh Perangkat Desa, seluruh Tokoh Agama/Gereja, pemuda dan mahasiswa yang berasal dari Desa Raanan Baru. Adapun yang menjadi narasumber dalam kegiatan ini yaitu tiga (3) orang dosen Jurusan Biologi FMIPA UNIMA, sebagai berikut:

1. Dr. Tommy Martho Palapa, MPd.;

2. Dr. Alfonds Andrew Maramis, M.Si.; dan

2. Dr. Decky D. W. Kamagi, M.Si.

\section{Tahapan Kegiatan}

Pelaksanaan kegiatan dilaksanakan dalam bentuk tahapan sebagai berikut :

1. Pelatihan peserta, mencakup:

$\begin{array}{ll}\checkmark & \text { Inventarisasi materi yang } \\ & \text { dibutuhkan peserta } \\ \checkmark & \text { Penentuan peserta pelatihan }\end{array}$
$\checkmark$ Penentuan lokasi dan waktu pelaksanaan
$\checkmark$ Pelaksanaan kegiatan pelatihan

2. Praktek penanaman pohon untuk wilayah yang telah terjadi penebangan pohon. Kegiatan penanaman merupakan implementasi dari materi pelatihan peserta dengan melibatkan seluruh peserta pelatihan ditambah dengan utusan masyarakat di wilayah kerja masing-masing. Adapun tahapan kegiatan sebagai berikut :

$\checkmark$ Menentukan spot penanaman pohon sebagai daerah sasaran

$\checkmark$ Mengadakan kordinasi dan pembagian kelompok berdasarkan daerah sasaran penanaman

$\checkmark$ Mengadakan kegiatan penanaman di bawah kordinasi ketua kelompok

$\checkmark$ Mengumpulkan laporan kegiatan dari tiap-tiap kelompok tentang semua kegiatan yang telah dilaksanakan pada penanaman pohon.

3. Evaluasi tingkat keberhasilan kegiatan. Evaluasi kegiatan dilaksanakan untuk mengukur sejauh mana tingkat keberhasilan kegiatan sesuai dengan tujuan pelaksanaan serta bagaimana dampak terhadap perilaku masyarakat setelah pelaksanaan kegiatan berlangsung. Adapun hal-hal yang menjadi materi evaluasi adalah peningkatan pengetahuan masyarakat tentang pentingnya pelestarian hutan sebagai satu ekosistim yang merupakan 
sumber daya alam (SDA) yang dapat menunjang kelangsungan hidup manusia baik dari fungsi ekologis maupun aspek penunjang ekonomi. Selain itu juga dievaluasi sejauh mana dampak kegiatan terhadap sikap dan perilaku masyarakat terhadap pelestarian hutan.

Mengukur tingkat pengetahuan masyarakat diukur dengan mengguakan format angket yang diisi oleh seluruh peserta pelatihan, sedangkan untuk mengukur sikap dan perilaku masyarakat dilaksanakan dengan mengadakan pengamatan langsung terhadap kegiatan masyarakat seharihari menyangkut upaya pemeliharaan seperti menghidari penebangan hutan, mencegah kebakaran hutan serta upaya untuk menghindari pengrusakan hutan secara sebarang.

\section{HASIL DAN PEMBAHASAN}

Berdasarkan kegitan yang telah dilaksanakan dalam kegiatan ini, makan diperoleh hasil kegiatan sebagai berikut:

1. Pengetahuan Masyarakat. Salah satu parameter penilaian untuk mengukur tingkat keberhasilan kegiatan pengabdian masyarakat ini adalah bagaimana peningkatan dan penguasaan pengetahuan masyarakat tentang pentingnya pelestarian lingkungan, khususnya pelestarian hutan lindung di sekitar gunung Lolombulan. Peningkatan kemampuan pengetahuan ini diukur dengan menjalankan angket pada masyarakat. Angket ini dijalankan pada masyarakat secara acak dengan jumlah 30 orang responden.

Berdasarkan angket yang terkumpul dapat disimpulkan bahwa $80 \%$ responden tergolong kategori menguasai dasar-dasar pentingnya pelestarian hutan lindung yang ada di sekitar gunung Lolombulan, $20 \%$ sisanya masih perlu penguatan pengetahuan dengan memberikan contoh yang nyata dalam kehidupan sehari-hari. Selain itu lebih dari $60 \%$ responden memiliki pengetahuan praktis yang diperoleh dari cerita turun temurun dari masyarakat seperti pemahaman tentang perlunya memelihara pohon yang ada di sekitar sumber air yang ada.

2. Sikap dan Perilaku. Sebagaimana dikemukakan pada uraian terdahulu bahwa sikap dan perilaku merupakan manifestasi dari pengetahuan seseorang tentang sesuatu yang diketahui seseorang. Dalam hubungan dengan upaya pelestarian lingkungan hidup khususnya pelestarian hutan dalam kegiatan ini pengetahuan yang diperoleh dalam kegiatan pelatihan dapat mendorong sikap dan perilaku seseorang terhadap upaya pelestarian hutan. 

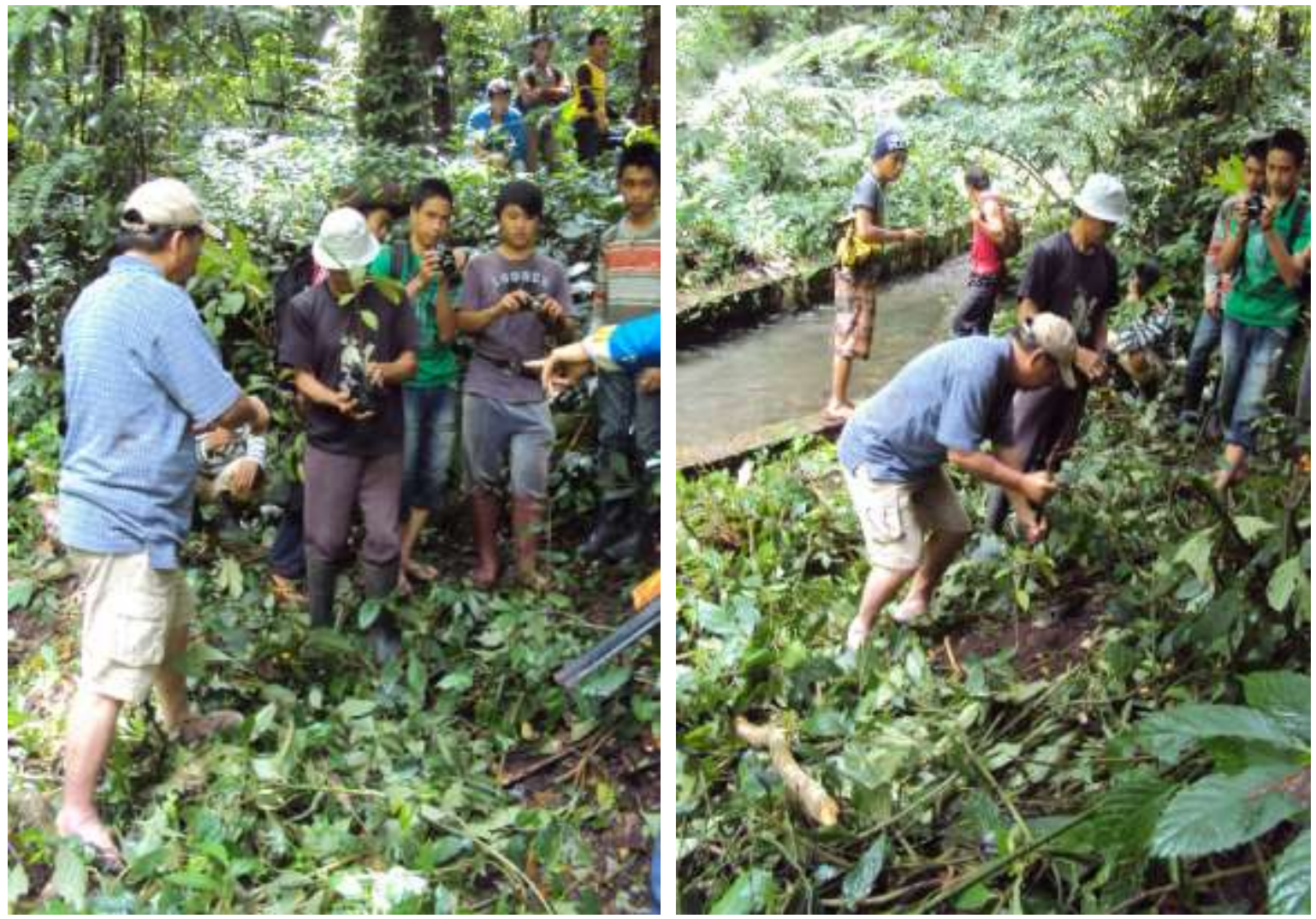

Gambar 1. Dokumentasi kegiatan: penjelasan teknis dan penanaman pohon di lokasi.

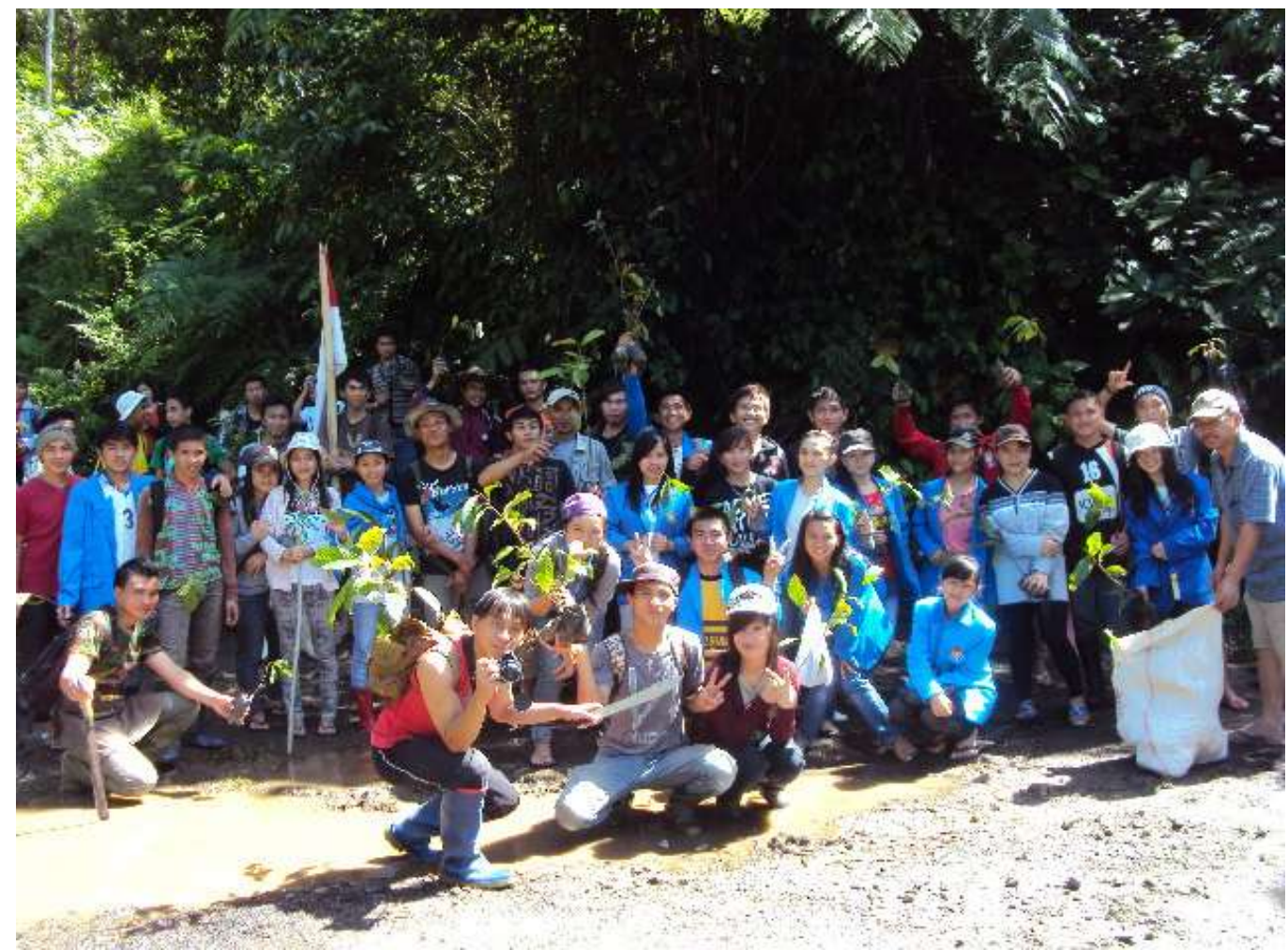

Gambar 2. Dokumentasi kegiatan: peserta kegiatan penanaman pohon. 

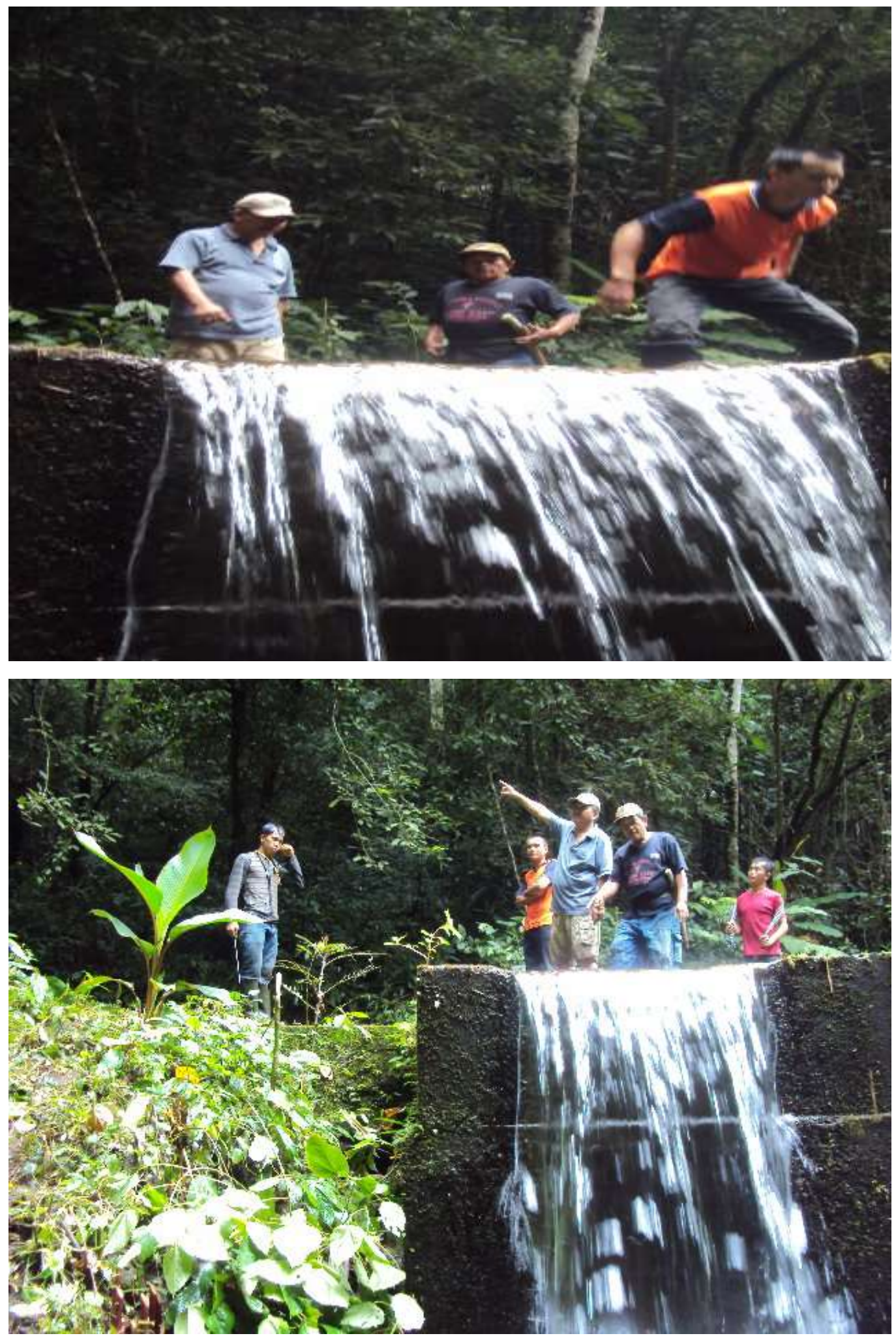

Gambar 3. Dokumentasi kegiatan: lokasi sasaran penanaman pohon.

Sehubungan dengan hal tersebut maka dilakukan evaluasi secara kualitatif terhadap perilaku masyarakat sekitar hutan menyangkut upaya pelestarian yang terkait dengan kehidupan sehari-hari seperti membati penebangan hutan, penanaman 
pohon di daerah yang sudah tandus, mengadakan penyadaran pada masyarakat tengtang pentingnya pelestarian hutan, pemanfaatan air dengan bijaksana.

Berdasarkan hasil pengamatan diperoleh data bahwa secara umum kegiatan pengabdian membawa dampak positif pada sikap dan perilaku masyarakat desa Raanan Baru dan sekitarnya. Hal ini ditunjukkan dengan berkurangnya/tidak terjadi penebangan hutan secara sebarang serta terjadi informasi secara terusmenerus melalui lembaga dan kelompok masyarakat untuk melestarikan hutan yang ada di gunung Lolombulan.

\section{KESIMPULAN DAN SARAN}

\section{Kesimpulan}

Berdasarkan beberapa uraian dan hasil kegiatan yang telah diungkapkan di atas dapat disimpulkan bahwa :

1. Terdapat peningkatan kemampuan pengetahuan masyarakat tentang pelastarian lingkungan khususnya pelestarian hutan

2. Terjadi perubahan sikap positif masyarakat tentang pentingnya pelestarian hutan lindung di gunung Lolombulan

3. Terjadi perilaku positif masyarakat terhadap upaya pelestarian hutan lindung di gunung Lolombulan.

\section{Saran}

1. Perlu dilakukan kegiatan pelatihan dan partisipasi langsung dari seluruh masyarakat melalui kolompok masyarakat untuk bersama-sama melestarikan lingkungan khususnya hutan.

2. Sudah saatnyaPerlu upaya penerapan supremasi hokum bagi para pelakupelaku perusak lingkungan terutama perambah liar yang ada di sekitar hutan lindung.

\section{KEPUSTAKAAN}

Anonim, 1999, Undang-Undang No. 22 Tahun 1999 tentang Pmerintahan Daerah , 1999, Undang-Undang No. 25 Tahun 1999 tentang Perimbangan Keuangan Antara Pmerintah Pusat dan Daerah , 1999, Undang-Undang No. 41 Tahun 1999 tentang Kehutanan

, 2000, Perturan Pemerintah No. 25 Tahun 2000 tentang Kewenangan Pemerintah dan Pemerintah Propinsi Sebagai Daerah Otonom

Iskandar, Untung, 2000, Makalah Lokakarya: Perumusan Program Litbang, Menimbang Manajemen Hutan dan Perkebunan pada Era Desentralisasi dan Otonomi Daerah.

Marsono Joko, Ahmad Sulthoni, 1999, Makalah Seminar: Perspektif Ekosistem Pengelolaan Sumberdaya Alam dalam Rangka Otonomi Daerah.

Silalahi, Pande Radja, 2000, Implikasi Kabijakan Ekonomi Pemerintah Pusat dan PembangunanEkonomi di Daerah, Analisis CSIS, tahun ke XXIX/200, no. hal.97

Warsito, Sofyan, P., 1999, Makalah Seminar: Perspektif Ekonomi Pengelolaan Sumberdaya Alam dalam Rangka Otonomi Daerah 
Jurnal ABDIMAS, Vol. 11, No. 1, April 2018

ISSN: 1979-0953 | e-ISSN: 2598-6066 